International Journal of Instruction e-ISSN: 1308-1470 • www.e-iji.net

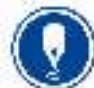

Article submission code: 20200306211307
Received: 06/03/2020

Revision: 23/08/2020
April 2021 • Vol.14, No.2

p-ISSN: 1694-609X

pp. $45-66$

Accepted: 16/09/2020

OnlineFirst: 03/01/2021

\title{
Special Aspects of Effective PR Professionals' Training in the Post-Truth Era
}

\section{Andrii Kyrychok}

Assoc. Prof., National Technical University of Ukraine Igor Sikorsky Kyiv Polytechnic Institute, Kyiv, Ukraine, kyrychok.andrii38@yahoo.com

In recent years, the post-truth era has become the new reality of the modern digital world, requiring changes in approaches to training public relations (PR) specialists. In such conditions, the classical image-based approach to education is not always effective when choosing professional competencies. The latter increases the need to involve relevant specialists to resolve complex controversies. This is the task today that should be entrusted to PR professionals. The objective of this article is to study the main aspects of effective organization of PR training. For this aim, the self-selection sampling technique is used. The sample population comprises people who responded positively to the proposal to engage in an online survey posted on a specially designed for this purpose website. The authors have conducted a sociological survey of experts in the field of PR, advertising, journalism, marketing and education $(n=100)$ in order to determine the main methodological aspects, approaches and principles of PR professionals' training. It has been identified that in the training of PR professionals the most effective methods of gaining practical knowledge are the case study method, the business game method and the project task method. All three methods are group methods, with the help of which a PR professional can develop almost all the necessary competencies. Such methods should be used in conjunction with other practical approaches, seminars, lectures, and mixed methods that combine qualitative and quantitative approaches and pragmatically draw on distinct research paradigms.

Keywords: public relations, PR education, mentoring approach, innovative teaching methods, case study, project assignment method, business games

\section{INTRODUCTION}

The modern democratic society is based on trust. However, in the post-truth world, there is a distortion of facts, as well as the creation and dissemination of lies, which poses a significant threat to preserving and maintaining stability in relation to established democratic institutions and structures. Therefore, training trustworthy PR specialists who can contribute to the information sphere and maintain public authority in the posttruth world is extremely important. 
Globalization is strengthening economic, social and political interdependencies around the world (Verčič, 2013; Verčič et al., 2015). At the same time, communication is a strategic asset of the organizations in the new post-truth environment, and much of the ethical weight rests on public relations (Ihlen et al., 2019). Consequently, public relations is more commonly used as a discipline when managing communication and relations between organizations and their stakeholders at the international level.

Public relations education is gaining popularity today among young people (Xifra, 2007; Ewing et al., 2019). On the one hand, every country needs high-quality professionals in this field (Alonso et al., 2019), on the other - the existing training programs do not meet the demands of today's job market (Neill \& Schauster, 2015). In many countries, the following algorithm in the education system is not taken into account in professional training. Namely, the state provides the university with state orders for training specialists in the relevant field. At the same time, the labor market puts forward the necessary competencies that a specialist must have in order to be a professional in the relevant field (Nolte, 2016). Further, the university builds an education system based on a competent approach to train specialists of the appropriate level, required by the state and relevant industry (Wright \& Flynn, 2017).

Quite often, this algorithm is violated, and then the training system mismatches the requirements of the labor market and the problem of low competence of specialists arises (Cotton \& Tench, 2009). There are a large number of gaps and inconsistencies that make it impossible to organize adequate, up-to-date training for PR specialists. Therefore, there is a problem of finding methods and approaches for organizing the system of training of high-level PR specialists (Pieczka \& L'Etang, 2006). Utilizing innovative tools and approaches to educate future competent professionals is an indicator of effective education that provides state-of-the-art high-level professionals (Michael \& Gorpe, 2017). PR professionals develop during academic training (Tench \& Konczos, 2013). However, apart from primary university education, communications professionals in Europe rely on professional associations and commercial training providers to further their professional development.

Recently, Ukraine has switched to a specialist training format that is based on the acquisition of competencies that are required for a student's future professional career (Kovtun \& Stick, 2009). An important aspect is to identify those disciplines that will allow mastering the required professional qualities of a PR specialist. Another important point is the transition to a pan-European three-tier educational model, which aims to democratize and improve the process of acquiring the necessary competencies by specialists (Kyrychok, 2017). In addition to the general principles of training, there are questions of methodological organization of the educational process. This means that the identification of the most relevant innovative methods and approaches to the organization of PR-education is becoming more relevant (Pieczka, 2002).

Activity becomes a profession when team members decide to acquire certain competencies and follow certain behavioral norms (Picciotto, 2011). That is, professionals should not violate ethical standards (Neill, 2017) and behavioral norms, must have a certain knowledge base, should demonstrate loyalty to colleagues and 
maintain quality standards in professional life. Unfortunately, the use of the term "professionalism" in public relations is usually associated with the expression of the need to improve professional standing (Pieczka, 2000; Bowen 2007).

Boston University scientists in their study (Cameron et al., 1996) identified several attributes of professionalism in public relations that cover the following:

- skills and activities;

- wage levels;

- use of research work;

- the role of public relations in the organization;

- ethics;

- racial and gender equality;

- accreditation, licensing as well as education.

In 2009, Glen Broom identified five indicators of professional status. Thus, an area of practice can be considered a "profession" only if it has:

- specialized educational training;

- base of theoretical works;

- codes of ethics and standards;

- the right to practice freely within the framework of legal and ethical standards;

- the recognition by society that the industry offers unique and important services (Broom, 2009).

In recent decades, the public relations field has undergone constant changes, extensions and improvements. Communication is no longer perceived as an end in itself, but is accepted as a tool for positioning and recognizing business in society. Public relations is developing fast and today the industry most needs tools for sound assessment of vocational education in this area (Lattore, 2005). Professional competence is the qualification that practitioners need to perform certain tasks (Sha, 2010; 2011). All the necessary competencies of PR specialties are identified in reports of US Commission on Public Relations Education. These competencies include: knowledge of ethical and legal norms and standards; writing skills; research and analysis skills; strategic planning skills (Leuven, 1999; DiStaso et al., 2009). Public relations practitioners need communication skills, media and management skills, problem-solving skills, motivation, analytical skills, writing skills and understanding of specific activities or industries, the ability to communicate with people and deal with stress, and also the desire to develop constantly (Broom, 2009). However, with the advancement of technology and in the light of economic and social changes, current PR practices should review existing competencies and add other skills that may affect the overall competence of professionals. In addition, there is the need to carry out a thorough examination and record of professional competences (Sha, 2011).

It is important to outline PR specialist's skills and experience (Thurlow et al., 2018) needed to further integrate and develop within the organization structure. Technologies and globalization affect PR practices and, consequently, educational programs that prepare future professionals for their jobs (Jugo et al., 2017). While developing courses 
and curricula, an important issue for public relations teachers is (Krishna et al., 2020) to understand the core competencies and tools as well as learning outcomes that are to be achieved. Individual researchers, when reviewing communication competencies, identify seven major areas, namely:

- theoretical aspects of communicative discipline;

- technical communication skills;

- organizational environment and processes;

- peripheral context;

- research and analytical capabilities;

- interpersonal abilities;

- personality or character traits (Fuller et al., 2018).

Recently, the definition of "professional" has become ambiguous. This is due to the overuse, misunderstanding and wrong policies of trade associations and unions. The purpose of this article is to analyze the main methodological components of PR specialists' training. The tasks of the work are to:

- conduct an online survey of experts in the field of social communications on the main components of the organization of PR specialists' training;

- provide practical guidance on the findings of the study.

\section{METHOD}

\section{Research design and sample}

The authors have organized a sociological survey to identify those components that are most needed in the preparation of competent PR specialists. The following components are identified for improving PR training system, namely:

- defining the basic methods and approaches to training;

- finding out the disciplinary principles that would help students to develop the competencies needed in the labor market;

- determining optimal balance of practical and theoretical load.

Respondents, who have participated in the survey, have been able to place disciplines in the order from the highest priority to the least priority. For convenience, the authors have created tables that fully reflect the results of the survey. Educational subjects in the tables are ranked by the popularity rating that has been determined by the integral evaluation. It is also stated how many times each discipline has been ranked

The purpose of the survey was to determine the list of methods and disciplines necessary for effective training of public relations professionals. In particular, it was necessary to find out the main directions of improvement and optimization of the disciplinary workload through:

- defining the priority disciplines of the professional-oriented and social-humane areas; - identifying most appropriate methods for acquiring practical skills;

- determining the proportion of theory and practice curricula for bachelors and masters of public relations. 
Since the subject of the study is the PR industry, which is now a fairly large group, it has been decided to use the sampling method. However, given the specifics of the study, the authors did not aim to generate a sample that would be statistically representative. At the same time, stable and well-founded statistical conclusions are obtained, which allow clarifying the main trends in the development of certain processes or phenomena.

\section{Participants}

In the process of conducting an online survey, a random self-selected sample of respondents (Bethlehem, 2008) was created after their voluntary agreement to engage in the form of a response to the proposal, posted on a specially designed for this aim website. In total, 100 people participated in the survey, including $60 \%$ of women and $40 \%$ of men, which, given the gender demographic statistics, showed that in the field of advertising, PR, marketing and social communications in Ukraine there are more women than men.

\section{Survey}

The sociological survey was carried out by means of an online survey method by sending questionnaires to the e-mail addresses of potential respondents or by giving the respondent access to the website of the research organization. In some cases, the Internet survey method was combined with other, more traditional, methods for interviewing groups of respondents not available through the Internet. The survey was conducted through the social networks "VKontakte" and "Facebook", where, using a link, one could go to the page with the online survey. A link was also sent to respondents' e-mails (Online survey of practitioners and teachers, 2018). The questionnaire was adapted for the online survey, dichotomous and scale questions were used to obtain the respondents' assessment, as well as the question-lists in the nominal variation scale, in which the study participants could choose several answers. At the beginning of the survey, questions were asked to evaluate respondents' competence and obtain statistics on their age, occupation, and position.

After the survey, a final analysis of the collected data was conducted. Statistical analysis of the survey results was performed using Excel.

\section{Materials}

Obtaining primary materials is one of the first and most significant steps in the research process, which can be ethically problematic. Therefore, the online survey data remained confidential and, according to the ethical principles, were used only for scientific purposes.

\section{Procedure}

Within the study, mixed research methods were used. They combined qualitative and quantitative approaches, drawing pragmatically on distinct research paradigms (Daymon \& Holloway 2011). At the first stage of preparing the survey, researchers carried out preliminary work to assess respondents' competence and obtain more data for a qualitative analysis of their age, profession, and social status. After this, all the 
participants were interviewed through a multiple-choice online questionnaire with several answers possible.

\section{Research limitations}

The main limitation of the study is the low sample size of the survey. The limited number of answers makes it difficult to generalize the results. In addition, at a more global level, another limitation may be the use of a single educational institution. The study has been conducted in one country, thus, further research is needed to confirm that the results can be generalized to other cultural contexts.

\section{RESULTS AND DISCUSSION}

The question about the area of activity contained seven answers that reflected different areas of activity of PR specialists. The largest number of respondents indicated PR as their area of activity $-31 \%$, the second place went to advertising - $27 \%$, the third place was taken by marketing $23 \%$, the fourth place - education and science $(18 \%)$, the fifth journalism (12\%), the sixth - exhibition activity (11\%). It was also possible to choose the option "Other", which gained 8\% (Fig. 1). This question was added to the questionnaire in order to assess respondents' competence in this area. There were several answer options.

In a follow-up question, respondents were asked to indicate their position. In total, five answer options were offered, each with several items to choose from. The largest number of respondents were experts $-44 \%$. This answer option means that the person is a specialist - a professional in his/her field. The second place was taken by teachers and scientists - 32\%. A significant proportion of respondents indicated this answer in conjunction with others. For example, one could choose the position of Head of Organization and in parallel, Teacher-Scientist. The third place was taken by the head of the unit $-16 \%$, in the fourth place - the head of the organization - $12 \%$. Respondents could also choose the answer "Other". There were $15 \%$ of them (Fig. 2). This question was posed to experts in order to obtain more detailed statistical information on their competence in this field.

\section{Area of activity}
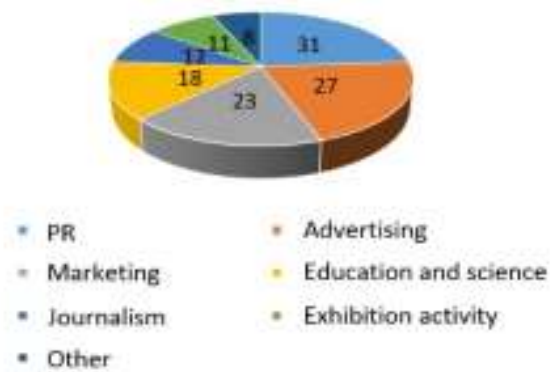

Figure 1

Respondents' answers regarding their area of activity (\%) 


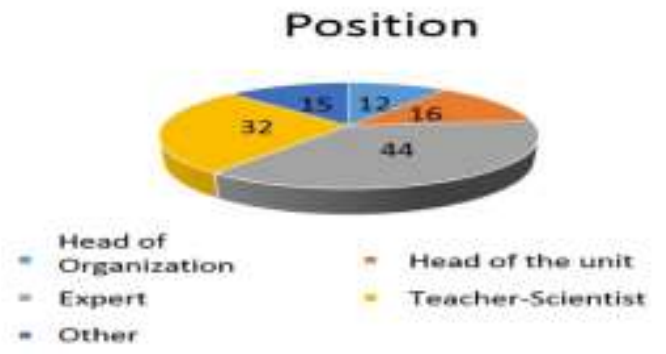

Figure 2

Respondents' answers regarding their position (\%)

The respondents were then asked two questions regarding disciplines in the training program. Disciplines were divided into two categories. The first - occupational-oriented disciplines, the second - social disciplines and humanities. Disciplines were selected on the basis of national educational and professional programs of the bachelor's and master's degrees. Both normative and variant parts were taken into account, except for those disciplines that might be integrated by the university itself.

In these questions, the respondents could place the disciplines in a sequence from the highest priority to the least priority discipline. For the reader's convenience, special figures were created to show the survey results (Figure 3-4). The first figure (Question \# 4) included 25 professional-oriented disciplines, thus, the discipline could take any of the first to twenty-fifth places, respectively. The second figure (Question \# 5) included 37 social science and humanities disciplines, so that each discipline could be placed from the first to the thirty-seventh position. Since one hundred respondents were interviewed, each discipline was selected one hundred times and this number was divided among all places in the ranking of the table. The disciplines in the tables are ranked by the popularity rating defined by the integral assessment. It is also stated how many times each discipline has been ranked in one or another place in the ranking

The integral assessment of disciplines is carried out as follows:

$I_{\mathrm{i}}=\sum_{j=1}^{k} g_{\mathrm{i} j} \cdot(k+1-j)$.

where $i$ - the number of disciplines, ${ }^{j}$ - place (rank) of the discipline, determined by experts, $k$ - number of disciplines, $g_{i j}$ - the number of experts that have put $i$ discipline on $j$ place. For a survey of subject-oriented disciplines $k=25$, the maximum possible integral estimation is $I_{1}=2500$. For the survey on social and humanities disciplines $k=37$, the maximum possible integral estimation is $I_{1}=3700$. 


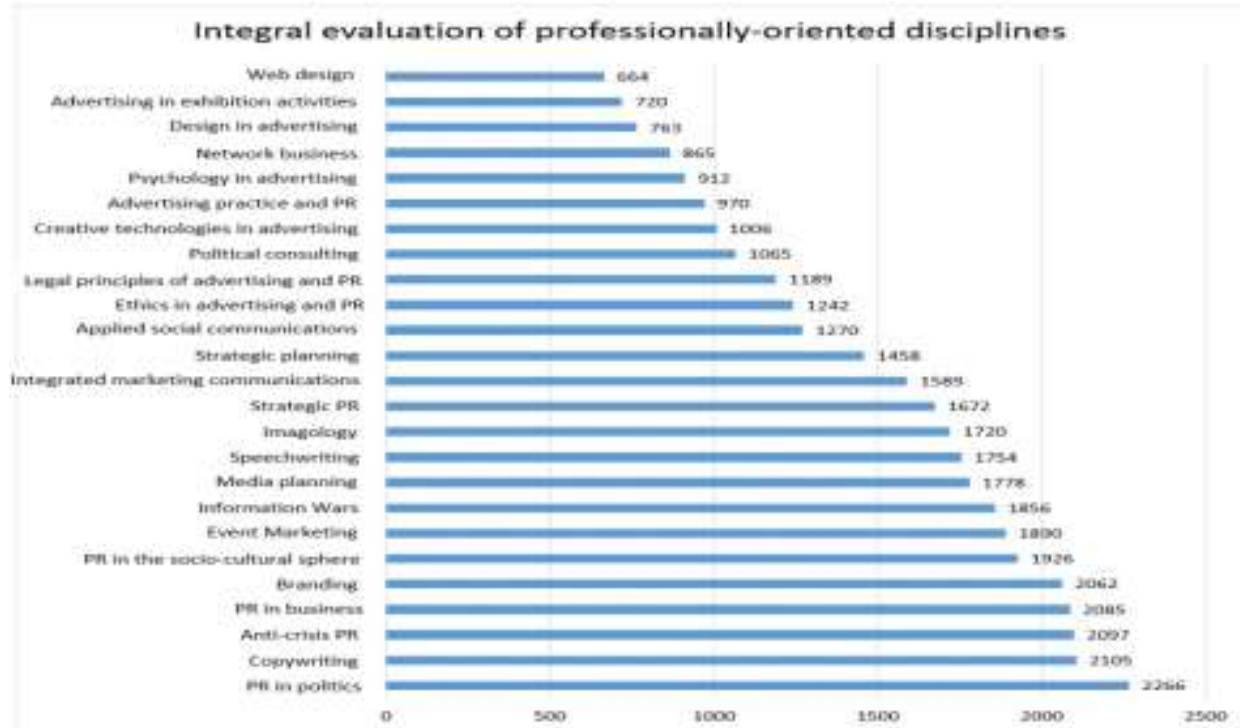

Figure 3

Integral evaluation of the professionally-oriented disciplines by their priority. The maximum possible score is 2500 points

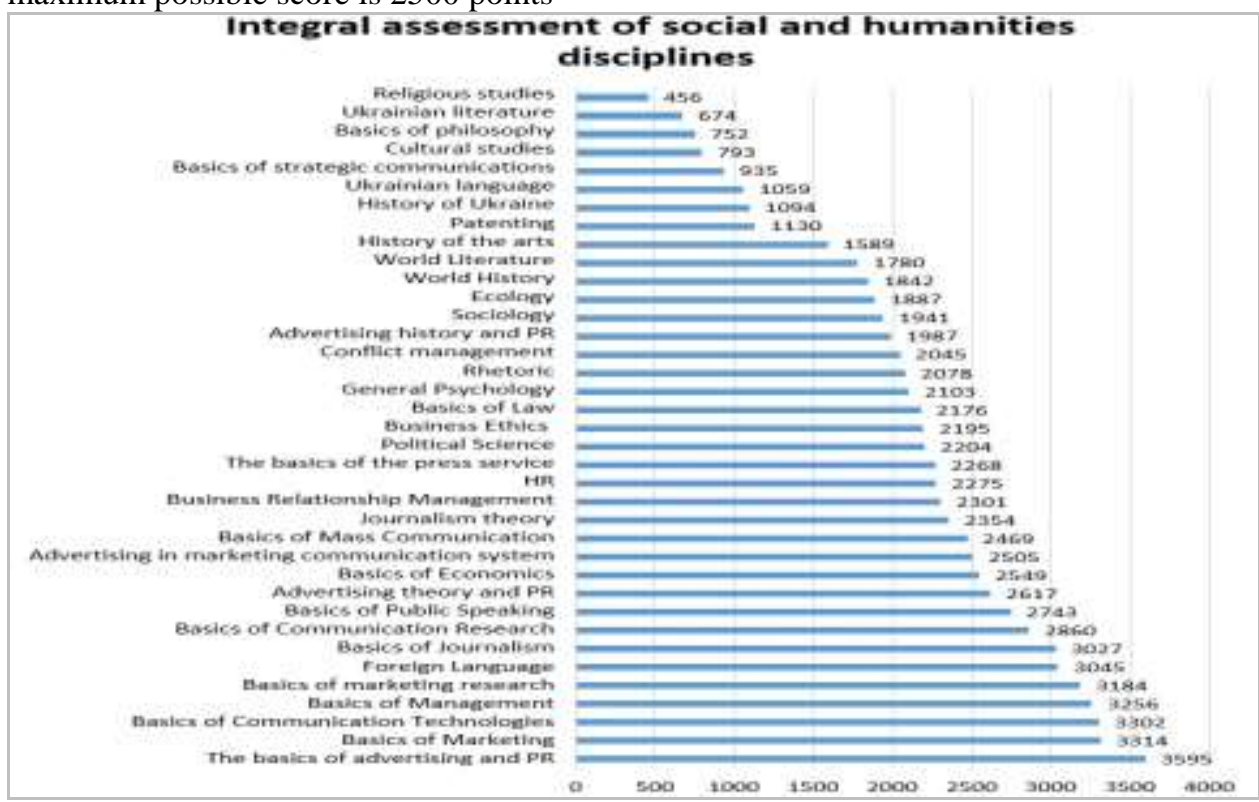

Figure 4

Integral assessment of social and humanities disciplines according to their priority. The maximum possible score is 3700 points

International Journal of Instruction, April $2021 \bullet$ Vol.14, No.2 
In question \#6 respondents were asked if they thought it advisable to use a mentoring approach (when an experienced employee shares knowledge and skills with an inexperienced newcomer or student over a period of time) when preparing PR professionals. An overwhelming majority $(83.1 \%)$ of respondents said they consider it effective. $7.9 \%$ do not consider this approach effective, $9 \%$ of respondents said that it is difficult for them to answer this question (Fig. 5).

The advisability of using a mentoring approach

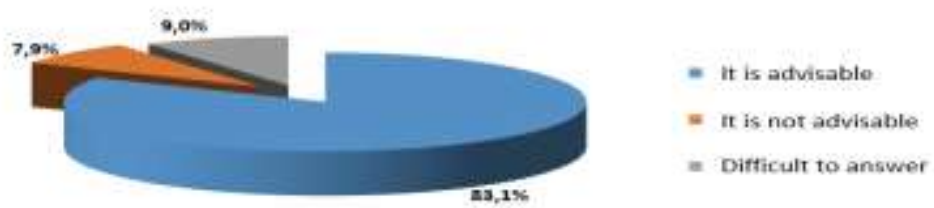

Figure 5

Respondents' answers regarding the advisability of using a mentoring approach in the training of PR professionals

Statistical analysis of the results of an integrated assessment of PR training programs by discipline priority revealed a higher coefficient of their variation $(39 \%)$ for the social and humanities disciplines. In contrast, for the professionally-oriented disciplines, it equaled only $34.3 \%$ (Table 1 ).

Table 1

Statistical characteristics of the results of disciplines evaluation

\begin{tabular}{lll}
\hline & $\begin{array}{l}\text { Integral evaluation of the } \\
\text { professionally-oriented } \\
\text { disciplines by their priority }\end{array}$ & $\begin{array}{l}\text { Integral evaluation of social and } \\
\text { humanities disciplines according } \\
\text { to their priority }\end{array}$ \\
\hline $\mathrm{N}$ & 25 & 37 \\
\hline Average & 1477 & 2118.5 \\
\hline Standard error & 101.4 & 135.7 \\
\hline Median & 1589 & 2195 \\
\hline Standard deviation & 507.2 & 825.4 \\
\hline Variation, \% & 34.3 & 39 \\
\hline Interval & 1602 & 3139 \\
\hline Minimum & 664 & 456 \\
\hline Maximum & 2266 & 3595 \\
\hline
\end{tabular}

The question regarding the most effective ways to acquire practical skills included six possible answers. Several options could be chosen, but no more than three. The experts chose the "case study method" - 84\% (Fig. 6) as the best method of gaining practical knowledge. Respondents put the "method of project tasks" in the second place $-75 \%$. "Business games method" was put in third place (with a difference of only 1\%) - 74\%. The fourth place was taken by the "explanatory and illustrative method" $-31 \%$. Fifth place belongs to "heuristic method", sixth - to "creative method". Since several answer options have been chosen, the percentage ratio is uneven and exceeds $100 \%$. 
The last two questions concerned the correlation of theory and practice in the curriculum for bachelors and masters of PR majors.

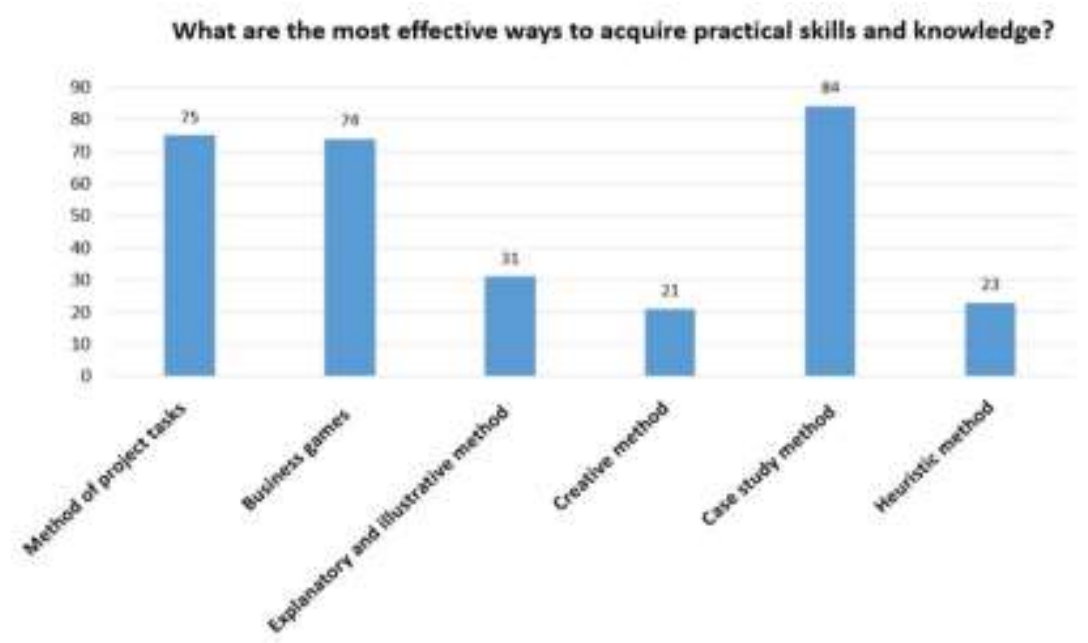

Figure 6

The most effective ways to acquire practical skills and knowledge, according to respondents

Question \#8 concerned bachelor educational level in this field. Most respondents, namely $64 \%$, said that practical training should dominate over theoretical training. $27 \%$ answered that the load should be distributed equally and only $9 \%$ said that the amount of theoretical training should be greater than the practical one (Fig. 7).

To the last question, the vast majority of experts $(78 \%)$ said that in the preparation of masters, the practical component should prevail. $16 \%$ of respondents believe that the load should be distributed equally, and only $6 \%$ said that theoretical training should prevail in the curricula (Fig. 8).

\section{Distribution between practical and theoretical training (bachelors)}

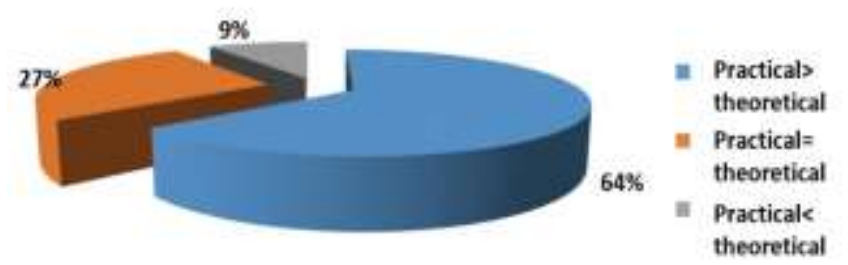

Figure 7

Respondents' answers on the distribution of practical and theoretical part in the preparation of PR bachelors 


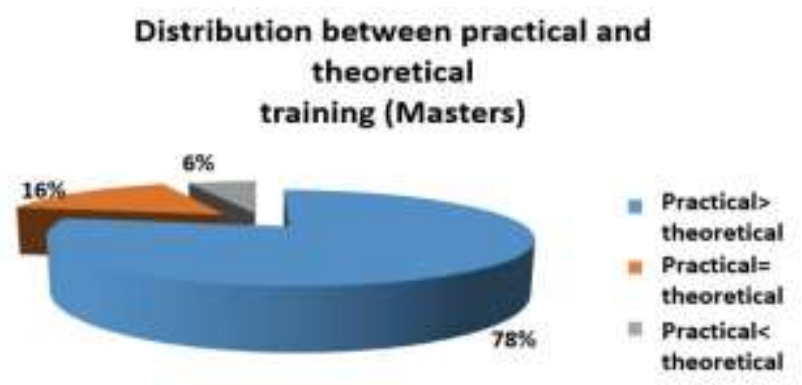

Figure 8

Respondents' answers on the distribution of practical and theoretical part in the preparation of PR Masters

The study identified the main components of an effective educational program for PR professionals. The authors propose training of specialists based on a competent approach to the educational process. It is this approach to the formation of educational programs that will cope with challenges posed by the "knowledge society" and, accordingly, the "knowledge economy". This approach recognizes the following important and effective aspects:

- generalized skills based on the acquired basic knowledge;

- communication;

- solving professional problems;

- knowledge of the latest information technologies;

- the ability to constantly update the formed system of knowledge (Fomina, 2012).

Bachelor's level of education provides basic social and humanities training for the student. Emphasis is placed on such disciplines as the fundamentals and theory of public relations, journalism, and the basics of sociology. Special attention should also be given to disciplines related to writing and speaking skills, psychology and communication basics. A bachelor's degree requires extensive basic training. A compulsory element of the educational program is the inclusion of social sciences and humanities disciplines. This list includes Ethics, Philosophy, Religious Studies, History of Ukraine and World's History, Ukrainian Language and Literature (Cameron et al., 1996). Competencies related to the linguistic aspect are quite important in the context of training PR professionals. The authors believe that foreign language learning should take place at all educational levels, with gradual refinement of language skills and an increase in the level of language from $\mathrm{B} 1$ to $\mathrm{C} 1$ or $\mathrm{C} 2$.

In the authors' opinion, the educational competencies of the master's level should be formed by the following professional-oriented disciplines: PR in the political sphere; copywriting; anti-crisis PR; branding; PR in the socio-cultural field; Internet marketing; information wars; media planning; speechwriting and more (Korolko, 2001). The aim of Master's degree education is to provide students with the opportunity to acquire and 
develop management skills and knowledge, to gain knowledge of crisis management and strategic management. In addition, Master's degree courses include industry-related disciplines in PR (PR in Politics, PR in Business and Social spheres). The Master's level of training is also the first stage in the preparation for the Doctor of Philosophy educational level, and accordingly, it also covers subjects related to the scientific component of education, such as the features of scientific perception and research, as well as basics of protection of intellectual law and PR-branch of science.

The Doctor of Philosophy is the third highest level of the three-level model of educational preparation. It corresponds to the eighth qualification level of the National Qualifications Framework and provides the theoretical and practical knowledge, skills and abilities sufficient to produce new ideas, solve complex problems in one's research and professional field. This educational level also involves methodological and pedagogical activities and the conduct of one's own scientific research, the results of which are of scientific novelty, theoretical and practical importance. Speaking of the $\mathrm{PhD}$ degree in Public Relations, it should be said that this level is theoretical, scientific and exploratory. During undergraduate training, the graduate student must develop the theoretical, scientific, and research skills that will be required for him/her to complete the public relations course. The $\mathrm{PhD}$ education level should prepare graduates for teaching, research and management positions at universities and for applied research in public relations (University of RMIT, 2018; New York University, 2018).

Another aspect of effective education for public relations professionals is the use of a mentoring approach. The mentoring approach involves mentoring communication between an inexperienced beginner in a particular industry and a professional (Kyrychok, 2016). In the educational process, mentoring is traditionally understood as a didactic, personal, long-lasting relationship between an experienced mentor and a student. In turn, the mentor not only acts as an educator but also develops in student professional, academic and personal qualities (Mentors Day, 2012).

An essential aspect of the mentoring approach is the ability to clearly articulate the purpose that the student faces in the course of his/her work with the mentor. The mentor's task is not only to ensure the student's learning goals, but also to stimulate the student's desire for self-development and work in this field. That is why the mentor uses a wide range of different forms of teaching and pedagogical influence. The main educational model of the mentoring approach is the model "Tell - show - do" (Lyon, 2008). First, the mentor should familiarize the student with the task, and if it is too large - help the student, then a mentor must make sure that the student understands the task. Next, the mentor should show how to perform a particular task, while commenting his/her actions, then he/she should also check that the student has understood everything, and ask the student to comment on everything. If a mentor is unsure of the quality of a particular task, he or she may dwell in more detail at a particular stage of work. The process of preparation for the mentoring program itself involves the passage of three consecutive stages. During the preparatory phase, the mentor gets to know the student beforehand. The main purpose of this step is to establish normal contact between the mentor and the student in order for the knowledge transfer and reflection process to 
proceed normally. The process then proceeds to the organizational and activity stage. This stage is fundamental in the formation of professional competences of a student, who is in practical training or engaged in independent work. The main goal is to nurture the necessary skills and qualities that the student will need in the future. At this stage, the mentor constantly monitors the student's work and adjusts the process as needed; it is also very important to put into practice the obtained knowledge.

The third stage - diagnostic - is crucial in the formation of competencies. The main purpose of this stage is to determine the degree of professional competence of a specialist and to make recommendations for the student. Effective mentoring training should last a year, but, considering the realities of domestic education, it is quite difficult to fulfill this condition. In the preparation of public relations professionals, the authors propose to use mentoring in conjunction with an internship. Applying a mentoring approach is only advisable in the undergraduate courses.

The mentoring approach is, first and foremost, aimed to help the PR student learn how to work in a team, create a quality information product and properly shape public opinion. As the work environment often requires collective action, the mentor should pay great attention precisely to ensure that the student works in a team and does not have difficulty with it. The tutor should assist the student in an unobtrusive form. If the mentor sees that the student is able to cope with the task, then he/she should only watch. The most rewarding experience is the experience gained on its own. The mentor has to provide direct assistance only when it is necessary. The focus should be on business communication between the mentor and the mentee, during which the experience is exchanged. In combination with practical work, this approach gives maximum effect.

The third important component of organizing the educational process for public relations professionals is the use of innovative teaching methods. The authors have chosen three innovative teaching methods: the case study method, the method of practical projects and the method of business games.

The case study method is an interactive teaching method that enables a student to become truly competitive in the labor market. Nowadays, this method is widely used in the field of training of public relations professionals. Before the start of the class, the teacher should find the most suitable case material, determine what material is needed and what is not, and compile a scenario for the class. The student, in turn, after receiving a case and a list of literature, individually prepares for the class to defend his/her opinion or position of the team. During the class, the teacher should organize a discussion of the case, then divide the group into subgroups and manage the discussion. The teacher may also provide students with some additional information. The student's task is to ask questions that give a better understanding of the case and the problem. The future specialist tries to work out solutions to the problem him/herself and in the team by making a single solution. After a lesson, teacher should evaluate the work of students, as well as the correctness of the decisions made and the relevance of the questions posed. The student, in turn, makes a written report on the topic of the case. After individual work, when students are divided into groups, there is a joint discussion of the problem. Subgroups begin to work collectively, develop a draft solution to a problem and present 
it in a classroom. The group also chooses: the "coordinator", who organizes the work; a "secretary", who records the results of the group's work, and "speakers", who represent the drafts developed by the subgroups. The sub-groups themselves are asked questions about how to solve a particular problem. This variant of the case study method is a classic format for conducting a class. Here are some examples of how it is advisable to use the case study method in training PR professionals.

The best example of implementing the case study method is a so-called media game for students (Pramuditya \& Sulaiman, 2019), the purpose of which is to develop the specific professional competencies of a public relations specialist. This game can be played between teams of one university, as well as in the format of competition between universities. Accordingly, this format involves many tasks. The groundwork can also be laid for collaboration between universities. It is this groundwork that will in the future coordinate the demands formed by the labor market and the possibilities of universities in matters of training PR specialists. Secondly, the great advantage is that students have the opportunity to interact with leading experts in marketing, journalism, advertising and PR, which in itself provides invaluable experience. In fact, in this case, both the mentoring approach and the case study method are used. It all depends on how to organize such an event and on what format to focus. Third, students, thus, develop the ability to work in a team that is an integral part of any work environment.

When referring to the method of project tasks, it should be said that the term "project" or "projection", implies the transfer of social subjectivity from today to the future (Savery, 2015). As a rule, project activity is of three types:

- a group project, which consists in the fact that a group of people is working on the task and each of its participants investigates a specific aspect of the activity;

- a mini-survey, which is a sociological survey that can also use questionnaires and interviews or focus groups;

- a project based on work with literature, which provides for the processing and analysis of literature, which is suitable for a given research topic (Reztsova, 2006).

There is another type of project activity - individual, when the student individually analyzes the situation, conducts research, and therefore develops an action plan and presents the results of work. The process of training PR professionals has certain features. The preparation covers six stages: development of a project assignment; preparation and organization of a PR-project; implementation of a PR project; presentation of a PR project; evaluating the effectiveness of a PR project; reflection.

A business game method is a method by which a work situation is imitated and the task is to make decisions that address a particular problem. Preparation for a business game involves three stages: preparatory, conducting a business game and the final stage (the stage of evaluating results). During the preparatory phase, one needs to write a script of the business game itself and prepare a place for a game. At the stage of the business game, the teacher is obliged to determine the purpose, roles and role relationships between all participants in the process. Teacher should also give clear instructions to 
each participant on what he or she should do. Teacher also gives the task to evaluate the game to those who do not play. During the game, the teacher should direct the group dialogue in the necessary direction, and if the process becomes protracted - give some clues. The teacher can also create new problematic situations, if the previous ones have been quickly resolved, and change the topic of discussion. An indispensable element of a business game is to discuss both the overall structure and each element. The evaluation stage is that the teacher listens to the opinion of the so-called "expert group", which consists of students who do not participate in the game. Their job is to make sure that all the rules of the game have been followed and how each participant has played. Then the teacher and the experts discuss the process of the game and its positive and negative aspects.

It will be quite effective to use this method when studying the subject "Practice of advertising and PR activities". This discipline is professionally oriented, aimed at the development of highly specialized professional competences. The teacher should prepare a list of problematic situations that are inherent in the advertising and PR industry, provide students with material on the topic in order to prepare them for the class. Students can be divided into groups in the training session. All students need to promote one product, each group represents its brand of product, and it is also possible to market a new brand of product. To put students in more difficult conditions, a teacher can provide a limited budget, along with a list of all prices for media services, prices for all types of advertising media, for filming commercials, as well as prices for printing and souvenirs. The more price items are included, the better the learning effect will be. Each group is also provided with a budget, which may be different from the competitors' budget. After that, each group thinks over its PR campaign for a period of time. Next, it presents its PR promotion project, and those who do not participate in the game evaluate the groups together with the teacher. It will be the most appropriate to have no more than four and no less than two groups participating in the game. In this case, the teacher can evaluate all participants in the game. All three methods are inherently group methods. Taken together, these methods develop almost all the competencies that a public relations specialist needs. However, these methods should be used in conjunction with other practical methods, seminars, and lectures.

The practical significance of the research results lies in the possibility of further development and improvement of the PR specialists' training program. Besides, the obtained conclusions facilitate the participation of PR professionals in the international exchange of experience.

\section{DISCUSSION}

$\mathrm{PR}$, as a profession, is rapidly and continually developing. The growing influence of technologies and globalization on PR practice affects educational programs used to train future PR specialists (Chung \& Choi, 2012). Any PR professional needs to have specialized preparation in the discipline to adequately develop their work and be able to relate to the public (Almansa-Martínez \& Fernández-Souto, 2020). 
In this study, the basic principles of training PR specialists in the higher education system of Ukraine are studied. The considered individual approaches to training PR professionals are similar to those in other countries of the world. In particular, it concerns the choice of training methods for specialists and the general methodology of organizing the educational process. Individual researchers (Ferguson, 2018) consider the best ways to prepare students in the field of public relations. These researchers have posed the following problems: "What are the attributes of a successful public relations specialist? How can public relations best deal with major social issues? What is the most effective way of realizing the communication capabilities of campaigns?"

Organizations and educational institutions agree that PR professionals should receive specialized training to help them effectively meet the challenges of the future in the rapidly changing media, economic, social and technological space (Fuller et al., 2018). The profession of public relations specialist from a discursive point of view is being studied in (Bourne, 2019). The methodological framework presented in this article can be used in professional discourses that concern different training methods: protectionist PR discourses within one organization, PR in advertising and marketing, fragmentation of PR to create new varieties of disciplines.

A model of value-based public relations education in a diverse and multi-contextual society is being studied in (Azionya et al, 2019). This model is proposed for PR education, which is based on the experience of teaching 1000 students in South Africa. Its essence is to use a value-based approach and ethical principles to educate future public relations professionals. The authors consider it necessary, along with the formation of professional PR-values in students in a multi-contextual and diverse society, to develop empathic values in them as well.

The experience of different countries of the world in training PR professionals is considered. For example, a separate paper (Parsons, 2013) examines professional ethics in public relations and corporate communications in Canada. This paper states that there is no consistency in the content of students' studies or what results can or should be expected. The paper (Gonçalves et al., 2013) analyzes the international standards of PR education based on the experience of Portugal. The authors found that the content of the discipline "Research and evaluation of public relations" corresponds to $42.86 \%$ of the analyzed curricula, especially the curriculum of the discipline "Research Methods". However, it should be noted that these disciplines are not intended solely for PR research but for any communication research. With regard to "Introduction to PR", the authors have found that $71.43 \%$ of universities offer courses related to "Theory, origin and principles". Additional public relations courses (PR \& Law, Ethics, Planning \& Management, Case Studies) were found in $78.57 \%$ of the curricula. PR content is always integrated into a more open course, such as "Communication Ethics or Communication Law." Finally, the authors note that less than half of the bachelor's degree programs offer "Public Relations work/internships".

An overview of the necessary professional and academic skills in training public relations professionals in Canada is considered in this paper (Manley, 2016). The author states that in order to get into practice today, all beginners need a formal bachelor's and 
master's degrees in PR. In the coming years, it is expected that formal postgraduate education will become either a requirement or a significant prerequisite for obtaining a mid- and upper-level position.

Of interest is the overview of public relations practices in the Middle East, education and research from isolation to globalization (Creedon \& Al-Khaja, 2019), where these issues are addressed by the example of local universities. Training of PR specialists at University of Hassan II Casablanca is considered in the work (Noui et al., 2012). The work (Cernicova \& Palea, 2012) focuses on the development of awareness of potential PR professionals about their future profession through the research and web analysis of Romanian academic sites. Awareness analysis was conducted on the websites of 20 faculties identified by the Romanian Ministry of Education. For some faculties, public relations is found to be the main area of specialization, and for others (social sciences, art, political science or journalism) - an additional area. Researchers have established methodological approaches to the use of websites in training public relations professionals, including 4 areas:

- functional (aimed at helping students and teachers track useful information);

- documentary (in this case, the website is an archive of information for several purposes: tracking past activity, evaluating links with the academic world, providing accountability evidence, etc.);

- symbolic (since the website helps to consolidate and promote the image/identity of the organization);

- projection (future-oriented) goals.

The work (Wilder, 2020) studies implementation of the active learning technique in the PR bachelor's course. The author gives an example of the integrated strategic communication program at Washington State University and emphasizes the principles of its organization throughout the course of training public relations professionals.

\section{CONCLUSIONS}

The post-truth era became the new reality of the modern digital world, which resulted in the need for changes in approaches to PR specialists' training. In educational institutions, new ways of PR professionals' preparation in PR/Communications that remain trustworthy, contribute to the information sphere, and maintain public authority in the post-truth world, are gaining increasing importance.

The study identifies a list of disciplines, on which PR training should be focused. Among the specialized disciplines: "PR in the political sphere", "Copywriting", "Crisis PR", "PR in the field of business", "Branding". Among social and humanities disciplines: "Basics of Advertising and PR", "Basics of Marketing", "Basics of Communication Technologies", "Basics of Management", "Basics of Marketing Research". This made it possible to determine what disciplines should be prioritized when completing training programs at each of the three levels of education. It is important that student preparation takes place using a competent approach that provides 
a highly qualified PR education. In addition, such training should follow the principles of systematicity, consistency and continuity of the learning process.

It has been identified that in the training of public relations professionals the most effective methods of gaining practical knowledge are the case study method, the business game method and the project task method. These methods are an interactive technology that can be effectively used in the training of public relations professionals. Each of these methods has its own peculiarities and unique approaches. It is important that each of the three methods develops its own competencies. However, in sum, they are able to help the student to acquire almost all the skills and competencies necessary for the modern labor market. In order for a specialist to acquire as much practical knowledge and skills as possible, the practical component of training must outweigh the theoretical, in both bachelor and master programs. To do this, one needs to increase the number of hours allocated for practical training. In addition, it is important to increase the total time spent practicing so that students have more and more time to refine their professional skills.

Thus, in the survey of PR bachelors, the majority of respondents (64\%) answered that practical training should dominate over theoretical. At the same time, 27\% said that both theoretical and practical training should be distributed equally and only $9 \%$ said that the amount of theoretical training should be greater than practical.

The question regarding the most effective ways to acquire practical skills included six possible answers. Several options could be chosen, but no more than three. The experts chose the "case study method" - $84 \%$ as the best method of gaining practical knowledge. Respondents put the "method of project tasks" in the second place $-75 \%$. "Business games method" was put in third place (with a difference of only $1 \%$ ) $-74 \%$. The fourth place was taken by the "explanatory and illustrative method" - $31 \%$. Fifth place belongs to "heuristic method", sixth - to "creative method". Since several answer options have been chosen, the percentage ratio is uneven and exceeds $100 \%$

It has been argued that in order to enhance a specialist's competence, it is advisable to use a mentoring approach to training, as it helps to gain practical experience and nurture professional competencies. The mentoring approach is the final stage in organizing a training system for public relations professionals. Integration of this approach will allow inculcating in students certain competencies, providing them with valuable experience, business contacts and specific knowledge, which can be acquired only with the help of a mentor.

\section{REFERENCES}

Almansa-Martínez, A. \& Fernández-Souto, Ana-Belén (2020). "Professional Public Relations (PR) trends and challenges". El profesional de la información, 29/3, e290203.

Alonso, M. O., Calderón, C. A., \& Pérez, D. O. (2019). Pre-professional journalistic culture of Cuba, Ecuador and Venezuela: Motivation, expectations and professional experience of students of Journalism and Social Communication. Revista Latina de Comunicación Social, 74, 477-498. 
Azionya, C., Oksiutycz, A., \& Benecke, D. R. (2019). A model for value based public relations education in a diverse and poly-contextual society. Public Relations Review, 45(3), 101767.

Bethlehem, J. (2008). How accurate are self-selection web surveys. The Hague/Heerlen: Statistics Netherlands. Available online: https://peilingpraktijken.nl/wpcontent/uploads/2014/06/bethlehem04.pdf

Bourne, C. (2019). The public relations profession as discursive boundary work. Public Relations Review, 45(5), 101789.

Bowen, S. A. (2007). Ethics and public relations. Gainesville, FL: Institute for Public Relations.

Broom, G. M. (2009). Cutlip and Center's effective PR. Englewood Cliffs.

Cameron, G. T., Sallot, L. M., \& Lariscy, R. A. W. (1996). Developing standards of professional performance in public relations. Public Relations Review, 22(1), 43-61.

Cernicova, M., \& Palea, A. (2012). Developing awareness of the future profession for prospective public relations specialists. A web based analysis of Romanian academic sites. Procedia-Social and Behavioral Sciences, 46, 4244-4248.

Chung, W., \& Choi, J. (2012). Professionalism in public relations pedagogy: A comparative analysis of public relations curricula among the United States the United Kingdom, and South Korea. Journalism \& Mass Communication Educator, 67(4), 375391.

Cotton, A. M. \& Tench, R. (2009). Profiling the public relations undergraduate/bachelor and graduate/master programmes in Europe and beyond. In Berlin Spring Symposium, www. euprera. org, Erişim Tarihi (Vol. 2, p. 2012).

Creedon, P., \& Al-Khaja, M. (2019). An overview of Middle East public relations practice, education, and research from isolation to globalization. Journal of Public Relations Research, 31(3)-4, 84-96.

Daymon, C. \& Holloway, I. (2011). Qualitative Research Methods in Public Relations and Marketing Communications. Second edition. Routledge Taylor \& Francis Group. London and New York.

DiStaso, M. W., Stacks, D. W., \& Botan, C. H. (2009). State of public relations education in the United States: 2006 report on a national survey of executives and academics. Public Relations Review, 35(3), 254-269.

Ewing, M. E., Remund, D. L., \& Dargay, L. (2019). Developing a new generation of public relations leaders: Best practices of public relations undergraduate programs. Journal of Public Relations Education, 5(1), 31-69.

Ferguson, M. A. (2018). Building theory in public relations: Interorganizational relationships as a public relations paradigm. Journal of Public Relations Research, 30(4), 164-178. 
Fomina, S. N. (2012). Professional competence, competitiveness and employment of a specialist on youth work. Moscow.

Fuller, M., Heijne-Penninga, M., Kamans, E., van Vuuren, M., de Jong, M., \& Wolfensberger, M. (2018). Identifying competence characteristics for excellent communication professionals. Journal of communication management, 22(2), 233-252.

Gonçalves, G., de Carvalho Spínola, S., \& Padamo, C. (2013). Analysing public relations education through international standards: The Portuguese case. Public Relations Review, 39(5), 612-614.

Ihlen, Ø., Gregory, A., Luoma-aho, V., \& Buhmann, A. (2019). Post-truth and public relations: Special section introduction. Public Relations Review, 101844.

Jugo, D., Ciboci, L., \& Alavanja, M. (2017). Trends in education of communication professionals: The perspective of educators and employers in Croatia. Public Relations Review, 43(5), 998-1006.

Korolko, V. G. (2001). Public relations. Scientific fundamentals, methodology, practice. Kyiv.

Kovtun, O., \& Stick, S. (2009). Ukraine and the Bologna process: A case study of the impact of the Bologna process on Ukrainian state institutions. Higher Education in Europe, 34(1), 91-103.

Krishna, A., Wright, D. K., \& Kotcher, R. L. (2020). Curriculum Rebuilding in Public Relations: Understanding what Early Career, Mid-Career, and Senior PR/Communications Professionals Expect from PR Graduates. Public Relations Education, 6(1), 33-57.

Kyrychok, A. (2016). Special aspects of using a mentoring approach to training public relations specialists. Advanced education, 6, 82-86.

Kyrychok, A. (2017). The Main Determinants of Improvement of Model of Educational Training of Specialists in the Field of PR Based on Competency Approach. Future Human Image, 1(7), 71-85.

Lattore, P., \& Lumb, P. D. (2005). Professionalism and interpersonal communications: ACGME competencies and core leadership development qualities. Why are they so important and how should they be taught to Anesthesiology Residents and Fellows? In Seminars in Anesthesia, Perioperative Medicine and Pain (Vol. 24, No. 3, pp. 134137). WB Saunders.

Lyon, H. C. (2008). Mentoring. Retrieved from http://www.halclyon.com/Chapter14MENTORINGLyon91.11.07.htm

Manley, D. (2016). Crisis, what crisis? An overview of professional and academic credentials in Canadian public relations. Journal of Professional Communication, 5(1), 135-158. 
Mentors Day (2012). Retrieved from http://www.r-u-s.org/cgibin/news/view.cgi?news=554.

Michael, N., \& Gorpe, T. S. (2017). Public relations for the next generation: Middle East Public Relations Association (MEPRA)'s engagement with students. Learning and Teaching in Higher Education: Gulf Perspectives, 14(2), 1-13.

Neill, M. S. (2017). Ethics education in public relations: Differences between standalone ethics courses and an integrated approach. Journal of Media Ethics, 32(2), 118131.

Neill, M. S., \& Schauster, E. (2015). Gaps in advertising and public relations education: Perspectives of agency leaders. Journal of Advertising education, 19(2), 5-17.

New York University (2018). Educational program in the specialty "Media culture and communications". Retrieved from http://steinhardt.nyu.edu/mcc/doctoral/required_coursework

Nolte, L. W. (2016). Fundamentals of public relations: professional guidelines, concepts and integrations. Elsevier.

Noui, Z., Talbi, M., Fernex, A., Lima, L., Hadji, C., Gonegai, A., ... \& Radid, M. (2012). The role of public relations in the development and promotion of public structures: University Hassan II Mohammedia-Casablanca As a case in point. ProcediaSocial and Behavioral Sciences, 46, 114-119.

Online survey of practitioners and teachers (2018). Retrieved from http://anketolog.ru/s/133394/BZTLBLUk.

Parsons, P. (2013). COMM 3017 Ethics in Public Communication.

Picciotto, R. (2011). The logic of evaluation professionalism. Evaluation, 17(2), 165180.

Pieczka, M. (2000). Objectives and evaluation in public relations work: What do they tell us about expertise and professionalism? Journal of Public Relations Research, 12(3), 211-233.

Pieczka, M. (2002). Public relations expertise deconstructed. Media, Culture \& Society, 24(3), 301-323.

Pieczka, M., \& L'Etang, J. (2006). Public relations and the question of professionalism. Public relations: Critical debates and contemporary practice, 265278.

Pramuditya, S. A., \& Sulaiman, H. (2019). Development of instructional media game education on integral and differential calculus. In Journal of Physics: Conference Series (Vol. 1280, No. 4, p. 042049). IOP Publishing.

Reztsova, S. A. (2006). Telecommunication projects in teaching a foreign language. Modern theories and methods of teaching foreign languages. Moscow. 
Savery, J. R. (2015). Overview of problem-based learning: Definitions and distinctions. Essential readings in problem-based learning: Exploring and extending the legacy of Howard S. Barrows, 9, 5-15.

Sha, B. L. (2011). 2010 practice analysis: professional competencies and work categories in public relations today. Public Relations Review, 37(3), 187-196.

Sha, B. L. (2011). Does accreditation really matter in public relations practice? How age and experience compare to accreditation. Public Relations Review, 37(1), 1-11.

Tench, R \& Konczos, M. (2013). Mapping european communication practitioners competencies - A review of the European Communication Professionals Skills and Innovation Programme. ECOPSI (pp. 35-64).

Thurlow, A., Sévigny, A., \& Dottori, M. (2018). Global capabilities in public relations. Public Relations Journal, 11(3), 1-25.

University of RMIT (2018). Educational program in the specialty "Media and Communications". Retrieved from http://www.rmit.edu.au/study-with-us/levels-ofstudy/research-programs/phd/ dr211/\#pageId=DR211

Van Leuven, J. (1999). Four new course competencies for majors. Public Relations Review, 25(1), 77-85.

Verčič, D. (2013). Comparative research in public relations: from European to global research designs. In D. Ingenhoff (Ed.), Internationale PR-forschung. (pp. 11-20). Konstanz, Germany: UVK.

Verčič, D., Zerfass, A., \& Wiesenberg, M. (2015). Global public relations and communication management: A European perspective. Public Relations Review, 41(5), 785-793.

Wilder, C. A. (2020). Implementation of Active Learning Techniques in an Undergraduate Public Relations Course: Comparing Individual Social Networks and Brand Communities. Public Relations Education, 6(1), 99-112.

Wright, D. K., \& Flynn, T. T. (2017). Public Relations Education and the Development of Professionalization in Canada and the USA. In North American Perspectives on the Development of Public Relations (pp. 51-64). Palgrave Macmillan, London.

Xifra, J. (2007). Undergraduate public relations education in Spain: Endangered species?. Public Relations Review, 33(2), 206-213. 